\title{
Åndelig omsorg handler om mer enn religiøs tro
}

EPICC-standarden vil gi sykepleierstudenter kunnskap om å anvende åndelig omsorg i praktiske handlinger. Slik kan de ivareta en helhetlig sykepleie overfor pasientene.

\section{Britt Moene Kuven}

Førstelektor

Fakultet for helsefag, VID Vitenskapelige høgskole Bergen

\section{Bodil Bø}

Førsteamanuensis

Det helsevitenskapelige fakultet, Universitetet i Stavanger

\section{Venke Ueland}

Professor

Det helsevitenskapelige fakultet, Universitetet i Stavanger

\section{Tove Giske}

\section{Professor}

VID vitenskapelige høgskole, Bergen

EPICC standard

\section{Hovedbudskap}


I denne fagartikkelen presenterer vi en felles standard for utdanning i åndelig omsorg for alle sykepleier- og jordmorutdanninger i Europa, EPICC-standarden, samt et verktøy for selvvurdering. Standarden bygger på omfattende forskning, og både standarden og selvvurderingsskjemaet blir nå tatt $\mathrm{i}$ bruk i utdanninger over hele Europa. Målet er å omsette åndelig omsorg til praktisk handling og slik ivareta helhetlig sykepleie i møte med pasientene.

Mange norske sykepleierstudenter erfarer at det er tabu å snakke om åndelige forhold og Gud (1), og mange har aldri snakket med andre mennesker om håp og mening eller om tro eller utøvelse av tro (2).

Forskere og undervisere fra 21 europeiske land har utviklet en egen standard for utdanning i åndelig omsorg for alle sykepleierutdanninger i Europa (3). De har også utviklet et selvvurderingsverktøy som kan brukes av både sykepleiere og sykepleierstudenter (4).

Målet med standarden og selvvurderingsverktøyet er å kunne gi trygghet og videreutvikle sykepleieres kunnskaper, ferdigheter og holdninger innenfor temaet åndelig omsorg.

Sykepleieres helhetlige ansvar for pasientene innebærer å ivareta både fysiske, psykiske, åndelige og sosiale behov, herunder ansvaret for å understøtte håp, mestring og livsmot hos pasienten (5).

Samtidig viser forskning at åpenhet overfor pasienters åndelige spørsmål kan være en utfordrende og neglisjert del av sykepleien (4, 6-9). Sykepleierstudenter opplever spørsmål om åndelige forhold som private, og forskning viser at de unnlater å ta opp slike temaer både med pasienter, venner og familie (1).

\section{Hva er åndelig omsorg?}

Mange norske sykepleiere og sykepleierstudenter har lett for å tenke at åndelig omsorg er nært knyttet til religiøsitet $(8,10)$. Nyere definisjoner av åndelighet forklarer begrepet som et flerdimensjonalt fenomen som er unikt for hvert enkelt menneske.

Det er videre enn religiøs tro og handler om meningen med livet og forbindelsen til seg selv, andre mennesker og/eller høyere makter $(11,12)$.

\section{«Åndelig omsorg handler om mer enn pasienters tro eller livssyn.»}


I boken A ta vare på heile mennesket - en håndbok $i$ åndelig omsorg beskriver Giske og Cone åndelig omsorg som «å bry seg om heile personen gjennom medfølande omsorg, å kunne vera tilstades for den andre gjennom å lytte etter det som har betydning i pasientens liv, og ofte ved å legge praktiske forhold til rette» (1, s. 15).

Åndelig omsorg innebærer å møte pasientens behov og ressurser, altså hvordan den enkelte sykepleieren møter pasienten. Åndelig omsorg handler om mer enn pasienters tro eller livssyn; det handler om hvordan sykepleieren gjennom holdning og handling møter pasientens behov og utfordringer og bygger på den enkeltes ressurser og preferanser (2).

\section{Det er utviklet en felles standard for Europa}

Forskere og undervisere (31 personer) fra 21 europeiske land utviklet i 2016-2019 en felles standard for utdanning $\mathrm{i}$ åndelig omsorg for alle sykepleierutdanninger $\mathrm{i}$ Europa, EPICC Spiritual Care Education Standard (EPICC-standarden) (13, 14).

$\AA$ utvikle en slik felles standard ble mulig etter tildeling av Erasmus-midler. Styringsgruppen og deltakerne møttes fire ganger i løpet av de tre årene og utviklet læringsutbytter innenfor åndelig omsorg for sykepleier- og jordmorutdanninger i Europa $(3,13,14)$.

\section{Erasmus+}

Erasmus+ er EUs program for utdanning, opplæring, ungdom og idrett. Det er verdens største utdanningsprogram.

Erasmus+ støtter mobilitet og samarbeidsprosjekter i hele utdanningsløpet: barnehage, grunnskole, videregående opplæring, høyere yrkesfaglig utdanning, høyere utdanning og voksenopplæring.

\section{Kilde: Erasmus+}

Deltakerne i Erasmus+-prosjektet (13) hadde ulik tilnærming til hvilke roller sykepleiere og jordm ødre hadde i klinikken. I enkelte land bar arbeidsoppgavene preg av at både sykepleierne og jordmødrene var assistenter til legene, mens i andre land hadde sykepleierne et større selvstendig ansvar for pleie og behandling.

Deltakerne kom fra ulike kulturer når det gjaldt sykepleieres og jordmødres arbeidsoppgaver. Det var nødvendig å finne en definisjon av åndelighet som kunne romme kulturforskjellene, og samtidig samle gruppen til et felles utgangspunkt. 


\section{«Det var nødvendig å finne en definisjon av åndelighet som kunne romme kulturforskjellene.»}

I noen land var åndelig omsorg en integrert del av kulturen og væremåten, og det ble naturlig å snakke med pasientene om deres åndelige behov (for eksempel i SørEuropa).

I andre land var åndelige behov gjerne privatisert og noe man sjelden tok opp i samtaler med pasientene (for eksempel i Nord-Europa), mens i en del land var ikke åndelige forhold sentralt i sykepleieutøvelsen (for eksempel i Øst-Europa).

Med dette som bakteppe ble deltakerne enige om en definisjon av åndelighet og åndelig omsorg og utviklet kompetanser innenfor standarden (13-15).

\section{EPICC-standarden beskriver kjernekompetanser}

Arbeidet resulterte i en felles europeisk standard som beskriver innholdet $\mathrm{i}$ kompetansen som det forventes at studenter ved bachelor i sykepleie skal ha innen åndelig omsorg (14). Standarden er oversatt til norsk etter fastsatt prosedyre (16).

EPICC-standarden beskriver fire områder for kjernekompetanser i åndelig omsorg med tilhørende læringsutbytter relatert til kunnskaper, ferdigheter og holdninger (se tabell 1).

Standarden bygger på Association for Palliative Cares definisjon av åndelighet samt en tilpasning til National Health Service Educations definisjon av åndelig omsorg (4). Standarden definerer åndelighet som

«den dynamiske dimensjonen ved menneskelivet som er relatert til hvordan personer, både som individer og fellesskap, opplever, uttrykker og/eller søker mening, hensikt og transendens, og måten de er i kontakt med øyeblikket, til seg selv, til andre, til naturen, til det betydningsfulle og/eller det hellige» (4).

Forfatterne arbeider aktivt for at alle sykepleierutdanninger i Norge skal ta i bruk standarden. 
Tabell 1. EPICC Norsk. Standard for utdanning i åndelig omsorg

\begin{tabular}{|c|c|c|c|c|}
\hline & Kompetanse & $\begin{array}{l}\text { Kunnskaper } \\
\text { (kognitiv) }\end{array}$ & $\begin{array}{l}\text { Ferdigheter } \\
\text { (funksjon) }\end{array}$ & Holdninger (handling) \\
\hline 1 & $\begin{array}{l}\text { EGEN ÅNDELIGHET } \\
\text { Er oppmerksom på } \\
\text { betydningen av åndelighet } \\
\text { for egen helse og velvære. }\end{array}$ & $\begin{array}{l}\text { - Forstår begrepet } \\
\text { åndelighet. } \\
\text { - Kan forklare } \\
\text { innvirkningen } \\
\text { som åndelighet } \\
\text { har på personlig } \\
\text { helse og velvære } \\
\text { gjennom livet, for } \\
\text { en selv og andre. } \\
\text { - Forstår } \\
\text { innvirkningen av } \\
\text { egne verdier og } \\
\text { eget livssyn når } \\
\text { en utøver åndelig } \\
\text { omsorg. }\end{array}$ & $\begin{array}{l}\text { - Reflekterer over } \\
\text { sine egne verdier } \\
\text { og sitt eget } \\
\text { livssyn og } \\
\text { erkjenner at } \\
\text { disse kan være } \\
\text { forskjellige fra } \\
\text { andre personers. } \\
\text { - Tar vare på sitt } \\
\text { eget velvære. }\end{array}$ & $\begin{array}{l}\text { - Er villig til å utforske } \\
\text { sitt eget og andres } \\
\text { personlige, religiøse og } \\
\text { åndelige livssyn. } \\
\text { - Er åpen og respektfull } \\
\text { overfor andres ulike } \\
\text { uttrykk for åndelighet. }\end{array}$ \\
\hline 2 & $\begin{array}{l}\text { RELASJONELL } \\
\text { ÅNDELIGHET } \\
\text { Engasjerer seg i andres } \\
\text { åndelighet og bekrefter } \\
\text { deres livssyn og unike } \\
\text { åndelige og kulturelle } \\
\text { praksiser. }\end{array}$ & $\begin{array}{l}\text { - Forstår andres } \\
\text { måter å uttrykke } \\
\text { sin åndelighet på. } \\
\text { - Kjenner til ulike } \\
\text { livssyn / religiøse } \\
\text { oppfatninger og } \\
\text { hvordan disse kan } \\
\text { innvirke på } \\
\text { personers svar på } \\
\text { avgjørende } \\
\text { livshendelser. }\end{array}$ & $\begin{array}{l}\text { - Anerkjenner det } \\
\text { unike ved andres } \\
\text { åndelighet. } \\
\text { - Samhandler } \\
\text { med og ivaretar } \\
\text { andres } \\
\text { åndelighet. }\end{array}$ & $\begin{array}{l}\text { - Er ansvarsfull, } \\
\text { tilgjengelig og } \\
\text { respektfull i møte med } \\
\text { andres uttrykk for } \\
\text { åndelighet og ulike } \\
\text { livssyn / religiøse } \\
\text { oppfatninger. }\end{array}$ \\
\hline 3 & $\begin{array}{l}\text { ÅNDELIG OMSORG: } \\
\text { VURDERING OG } \\
\text { PLANLEGGING } \\
\text { Vurderer åndelige behov } \\
\text { og ressurser ved å bruke } \\
\text { formelle eller uformelle } \\
\text { tilnærminger samt } \\
\text { planlegger åndelig } \\
\text { omsorg, ivaretar } \\
\text { konfidensialitet og } \\
\text { innhenter informert } \\
\text { samtykke. }\end{array}$ & $\begin{array}{l}\text { - Forstår begrepet } \\
\text { åndelig omsorg. } \\
\text { - Er klar over ulike } \\
\text { tilnærminger til } \\
\text { vurdering av } \\
\text { åndelige forhold. } \\
\text { - Forstår andre } \\
\text { fagpersoners } \\
\text { roller når det } \\
\text { gjelder å utøve } \\
\text { åndelig omsorg. }\end{array}$ & $\begin{array}{l}\text { - Gjennomfører } \\
\text { og } \\
\text { dokumenterer en } \\
\text { vurdering for å } \\
\text { identifisere } \\
\text { åndelige behov } \\
\text { og ressurser. } \\
\text { - Samarbeider } \\
\text { med andre } \\
\text { fagpersoner. } \\
\text { - Er i stand til å } \\
\text { romme og } \\
\text { forholde seg til } \\
\text { følelser på en } \\
\text { hensiktsmessig } \\
\text { måte. }\end{array}$ & $\begin{array}{l}\text { - Er åpen, tilgjengelig og } \\
\text { ikke-dømmende. } \\
\text { - Er villig til å forholde } \\
\text { seg til følelser. }\end{array}$ \\
\hline 4 & $\begin{array}{l}\text { ÅNDELIG OMSORG: } \\
\text { INTERVENSJON OG } \\
\text { EVALUERING } \\
\text { Responderer på åndelige } \\
\text { behov og ressurser i en } \\
\text { omsorgsfull og } \\
\text { medfølende/ivaretakende } \\
\text { relasjon. }\end{array}$ & $\begin{array}{l}\text { - Forstår } \\
\text { betydningen av } \\
\text { ivaretakelse og } \\
\text { medmenneskelig } \\
\text { nærvær som en } \\
\text { del av åndelig } \\
\text { omsorg. } \\
\text { - Vet hvordan en } \\
\text { kan tilpasse sin } \\
\text { oppfølging av } \\
\text { andres åndelige } \\
\text { behov og } \\
\text { ressurser. } \\
\text { - Vet hvordan en } \\
\text { kan evaluere om } \\
\text { åndelige behov er } \\
\text { blitt møtt. }\end{array}$ & $\begin{array}{l}\text { - Erkjenner } \\
\text { personlige } \\
\text { begrensninger i } \\
\text { utøvelsen av } \\
\text { åndelig omsorg } \\
\text { og henviser til } \\
\text { andre ved behov. } \\
\text { - Dokumenterer } \\
\text { og evaluerer } \\
\text { personlige, } \\
\text { profesjonelle og } \\
\text { organisatoriske } \\
\text { forhold i } \\
\text { utøvelsen av } \\
\text { åndelig omsorg. }\end{array}$ & $\begin{array}{l}\text { - Viser } \\
\text { medfølelse/ivaretakelse } \\
\text { og nærvær. } \\
\text { - Viser vilje til å } \\
\text { samarbeide med og } \\
\text { henvise til andre } \\
\text { (profesjonelle/ikke- } \\
\text { profesjonelle). } \\
\text { - Er imøtekommende og } \\
\text { aksepterende og viser } \\
\text { empati, åpenhet, } \\
\text { profesjonell ydmykhet } \\
\text { og pålitelighet i søken } \\
\text { etter åndelig støtte fra } \\
\text { andre. }\end{array}$ \\
\hline
\end{tabular}




\section{EPICC-standarden inneholder fire kjernekompetanser}

De fire kjernekompetansene i standarden er: 1. Egen åndelighet, 2. Relasjonell åndelighet, 3. Vurdering og planlegging og 4. Intervensjon og evaluering (se tabell 1). For å gi mer konkret innhold i de ulike kompetanseområdene, gir vi noen eksempler på hva som ligger i den enkelte kjernekompetansen.

- Med kjernekompetanse 1 «Egen åndelighet» mener vi at studenten eller sykepleieren har oppmerksomheten rettet mot sin egen åndelighet og betydningen den har for egen helse og velvære.

- Kjernekompetanse 2 «Relasjonell åndelighet» omhandler at studenten eller sykepleieren engasjerer seg i pasientens oppfatning av åndelighet og er villig til å anerkjenne og vise respekt for den enkelte pasientens åndelige og kulturelle virkelighetsoppfatninger, livssyn og praksis.

- I kjernekompetanse 3 «Vurdering og planlegging» presenteres områdene som studenten eller sykepleieren skal beherske for å kunne vurdere pasientens åndelige behov og ressurser som en del av sin datasamling samt dokumentere og samarbeide med andre fagpersoner på området. Dette kan være i formelle eller uformelle sammenhenger der studenten eller sykepleieren ut fra datasamlingen planlegger videre oppfølging etter pasientens situasjon.

- Den siste kjernekompetansen, 4 «Intervensjon og evaluering», fordrer at studenten eller sykepleieren responderer på pasientens åndelige behov og ressurser på en omsorgsfull og medfølende måte som gjør at pasienten føler seg ivaretatt og respektert (se tabell 1).

De fire kjernekompetansene blir enda mer konkrete når vi leser beskrivelsen av de ulike læringsutbyttene som det forventes at studenter skal tilegne seg gjennom utdanningen når det gjelder kunnskaper, ferdigheter og holdninger innen åndelig omsorg (se tabell 1).

Sykepleiere i praksis har gitt uttrykk for at når de setter søkelys på de enkelte læringsutbyttene, blir åndelig omsorg mer konkret. EPICC-standarden kan bli et godt verkt $\varnothing y$ for å tydeliggjøre læringsbehov hos studenter med tanke på ut $\varnothing v e l s e n$ av åndelig omsorg.

Verktøyet gir konkret hjelp og belyser hvordan studenter og sykepleiere kan styrke kompetansen i utøving av åndelig omsorg i henhold til de fire kjernekompetanseområdene (4). 


\section{Studentene har fått et åndelig omsorgsverktøy}

Som en videreføring av arbeidet med EPICC-standarden innenfor åndelig omsorg har forskere utviklet et vurderingsverkt øy for studenter som muliggjør en selvevaluering av holdninger, ferdigheter og kunnskaper relatert til temaet åndelig omsorg.

Formålet med verktøyet er å øke bevisstheten om det åndelige området i sykepleie og synliggjøre om det er områder innenfor temaet som den enkelte student bør videreutvikle. Vurderingsverkt øyet er utviklet og testet av forskere ved universiteter og høgskoler i Norge, Nederland, England, Wales, Ghana og California (4).

\section{Tabell 2. Oversikt over deltakende studenter i forbindelse med uttesting av vurderingsverktøyet}

\begin{tabular}{|c|c|c|}
\hline Land (språk) & \# Inviterte studenter & \# Deltakende studenter* \\
\hline California (Engelsk) & $\begin{array}{l}330 \text { studenter, 2., 3. og } 4 . \\
\text { studieår, sykepleie, } 1 \\
\text { universitet, privat kristen }\end{array}$ & 33 \\
\hline England (Engelsk) & $\begin{array}{l}656 \text { studenter, 1., 2. og } 3 . \\
\text { studieår, sykepleie og } \\
\text { jordmor, } 1 \text { universitet, } \\
\text { offentlig }\end{array}$ & 56 \\
\hline Wales (Engelsk) & $\begin{array}{l}1400 \text { studenter, } 1 ., 2 \text {. og } 3 . \\
\text { studieår, sykepleie og } \\
\text { jordmor, } 1 \text { universitet, } \\
\text { offentlig }\end{array}$ & 38 \\
\hline Ghana (Engelsk) & $\begin{array}{l}131 \text { studenter, } 3 . \text { og } 4 . \\
\text { studieår, sykepleie, } 1 \\
\text { universitet, privat kristen }\end{array}$ & 75 \\
\hline $\begin{array}{l}\text { Nederland } \\
\text { (Nederlandsk) }\end{array}$ & $\begin{array}{l}700 \text { studenter, 1., 2., 3. og } 4 . \\
\text { studieår, sykepleie, } 1 \\
\text { universitet, privat kristen }\end{array}$ & 56 \\
\hline Norge (Norsk) & $\begin{array}{l}350+330+582 \text { studenter, } \\
\text { 2. og } 3 . \text { studieår, sykepleie, } 3 \\
\text { universiteter, } 2 \text { offentlige, } 1 \\
\text { privat kristen }\end{array}$ & 65 \\
\hline
\end{tabular}

Da vurderingsverktøyet ble testet, stilte forskerne studentene følgende spørsmål:

1. Hvor nyttig var verktøyet, og på hvilken måte?

2. Hvor tydelig var verktøyet? 
3. Hvor sannsynlig er det at du vil bruke verktøyet igjen?

4. Hvordan vil du forbedre verktøyet?

\section{Refleksjon ga studentene mer innsikt}

Flertallet av de norske studentene (46 av 65 studenter) svarte at verkt $\varnothing y e t$ var et nyttig redskap. De måtte tenke mer over spørsmålene for å kunne besvare dem, og de erfarte at å reflektere rundt spørsmålene ga dem mer innsikt i hva de kunne og ikke kunne.

Studentene fikk belyst sine egne styrker og svakheter knyttet til temaet. Noen studenter opplevde at det var utfordrende å fylle ut skjemaet, da de ikke helt forsto begrepene i kompetanseområdene. Totalt 18 av 65 studenter mente at verkt $\varnothing y e t$ var lite nyttig, og det begrunnet de på ulike måter.

\section{«Studentene fikk belyst sine egne styrker og svakheter knyttet til temaet.»}

Noen forsto ikke spørsmålene fordi temaet var ukjent, andre mente at åndelig omsorg var uviktig, mens enkelte syntes at spørsmålene var vanskelige. Noen få følte at spørsmålene var like, og at det var forvirrende.

Totalt 43 studenter svarte på spørsmålet om de ville bruke skjemaet igjen. De som kunne tenke seg å bruke det igjen, svarte «veldig sannsynlig», «sannsynlig» eller «kanskje». De skrev at det kunne bli en god påminnelse for å se deres egen utvikling over tid, eller at det kunne være et verktøy for å ha oversikt over hva det var viktig å huske på innenfor temaet.

\section{Det finnes barrierer for åndelig omsorg}

Sykepleiere og sykepleierstudenter har behov for å bli bedre rustet til å møte pasienters åndelige behov. På Helsebiblioteket (17) er det nå utviklet en egen kunnskapsbasert prosedyre som skal være en hjelp for helsepersonell til å ivareta pasienters åndelige behov.

Omfattende forskning har dokumentert betydelige barrierer for åndelig omsorg (6, 12, 18, 19). Barrierene handler i mange tilfeller om mangel på kompetanse, språk, tid, selvrefleksjon og redsel for å tråkke over pasientens grenser.

Hvidt (6) beskriver tre forhold som kan være avgjørende for at sykepleiere blir i stand til å yte faglig og personsentrert åndelig omsorg. Det første er å etterspørre pasientens egen overbevisning eller tro for å få bedre innsikt i åndelige utfordringer og ressurser. 
Det andre forholdet handler om at studenter og sykepleiere blir åpnere og bedre i stand til å samtale med pasienter om åndelige forhold. Det tredje er refleksjon over deres egne livsverdier og eget livssyn og hvordan livsverdier og livssyn kan bli utfordret i møte med pasientens livsverdier.

Selvvurderingsskjemaet kan på denne måten være et hjelpemiddel for sykepleiere og sykepleierstudenter til å bli mer bevisst på og reflektere mer over sitt eget ståsted samt forberede seg på å møte pasientenes åndelighet.

\section{Datainnsamlingsguider kan være nyttige}

For studenter er det hensiktsmessig å samtale om åndelige og eksistensielle forhold med pasienter gjennom å benytte anerkjente spørsmålsguider for åndelig omsorg. Det finnes mange datainnsamlingsguider, for eksempel Stolls datainnsamlingsguide, FICA eller HOPE (1).

Når studenter og sykepleiere setter seg inn i og blir trygge på hovedområdene i datainnsamlingsguider, kan spørsmålene tilpasses den enkelte pasient. Datainnsamlingsguiden HOPE (20) er også anbefalt i fagprosedyren om åndelig omsorg i Helsebiblioteket (21).

En studie av Giske og Cone (22) blant norske sykepleiere viser at samtaler om åndelig omsorg kan hjelpe pasientene til å mestre motgang og gi en opplevelse av indre fred. Studien viser hvordan åndelig omsorg har stor betydning i pasientenes liv ved å fremme en lindrende eller rehabiliterende prosess.

Weathers og medarbeidere (23) konkluderer i en oppsummeringsartikkel med at åndelig omsorg lindrer lidelse, øker opplevelsen av velvære, gjør pasienten i stand til å mestre motgang og kan gi en følelse av indre fred og styrke.

I tillegg viser studier at søkelys på åndelig omsorg kan øke håp og motivasjon og styrke følelsen av tilhørighet, medfølelse og kjærlighet $(17,24,25)$. Sykepleieres kompetanse innenfor åndelig omsorg er derfor sentralt for god sykepleie.

\section{Målet er å heve studenters og sykepleieres kompetanse}

Utviklingen av både EPICC-standarden og vurderingsskjemaet bygger på omfattende forskning og erfaring, og både standarden og selvvurderingsskjemaet blir nå tatt i bruk i utdanninger over hele Europa.

Målet er å heve kompetansen til studenter og sykepleiere slik at de kan omsette åndelig omsorg til praktisk handling og dermed ivareta helhetlig sykepleie i møte med pasientene. 


\section{«Sykepleierstudenter lærer at sykepleie er å ta vare på hele mennesket.»}

Sykepleierstudenter lærer at sykepleie er å ta vare på hele mennesket. Åndelig omsorg er en tydelig del av faget og et område studenter har behov for å bli tryggere på i løpet av studietiden.

Ved å bruke EPICC-standarden aktivt i landets sykepleierutdanninger vil studentene bli mer bevisst på sin egen utøvelse av åndelig omsorg og dermed bli godt forberedt på å ivareta pasientenes helhetlige behov.

\section{Konsekvenser for praksis}

SEP-gruppen (Spiritual Care Education and Practice Development) anbefaler at EPICC-standarden med sine fire kjernekompetanseområder blir tatt i bruk i undervisningen ved alle landets sykepleieutdanninger.

Vi anbefaler også at selvvurderingsskjemaet brukes aktivt både i første, andre og tredje utdanningsår, og at studentene selv kartlegger og vurderer sin egen kompetanse og utvikling i alle tre studieårene.

Dette er i tråd med yrkesetiske retningslinjer for sykepleiere, som vektlegger å underst øtte håp, mestring og livsmot og ivareta helhetlig omsorg i møte med pasientene (5).

Vi oppfordrer også alle ledere og fagsykepleiere til å sette åndelig omsorg på agendaen på den enkelte arbeidsplassen. Ved at ledere tar et aktivt ansvar for å sette temaet på dagsordenen, bidrar de til helhetlig og personsentrert sykepleie.

Den enkelte sykepleieren har også et selvstendig ansvar både for å sette seg inn i temaet åndelig omsorg og å lytte til pasientens egen fortelling om sine åndelige behov og ressurser.

Ved å benytte verktøyet kan sykepleiere kartlegge sin egen kompetanse i åndelig omsorg, og skjemaet gir mulighet til å vurdere deres eget nivå både på kunnskap, ferdigheter og holdninger innenfor de fire kjerneområdene. Slik kan sykepleiere stadig utvikle seg og sørge for at hver eneste dag blir så god som mulig for pasientene de har ansvar for. 


\section{Referanser}

1. Giske T, Cone PH. Å ta vare på heile mennesket - handbok i åndeleg omsorg. Oslo: Det Norske Samlaget; 2019.

2. Kuven BM, Bjorvatn L. Spiritual care - part of nursing? Christian Nurse International. 2015;5:4-8.

3. van Leeuwen R, Cusveller B. Nursing competencies for spiritual care. J Ad Nurs. 2004;48(3):234-46. DOI: 10.1111/j.1365-2648.2004.03192.x

4. VID vitenskapelige høgskole (VID). EPICC Norsk. Standard for åndelig omsorg. Kjernekompetanser i åndelig omsorg for bachelorstudenter i bachelorstudenter i sykepleie. Oslo: VID; u.å. Tilgjengelig fra: https://www.vid.no/filer/epicc-norsk-standard-for-utdanning-i-andelig-omsorg/ (nedlastet 15.09.2021).

5. $\quad$ Norsk Sykepleierforbund (NSF). ICNs etiske regler. Yrkesetiske retningslinjer for sykepleiere. Oslo: NSF; u.å. Tilgjengelig fra:

https://www.nsf.no/sykepleiefaget/yrkesetiske-retningslinjer (nedlastet 15.09.2021).

6. Hvidt NC. Eksistensiell og åndelig omsorg i Norden: hvorfor, hva, hvordan og hvem? HELE. Tidsskrift for fag og tro. 2020;1:4-11.

7. Baldacchino DR. Teaching on spiritual care: the perceived impact on qualified nurses. Nurse Educ Pract. 2011;11(1):47-53.

8. Giske T, Cone PH. Opening up for learning: a grounded theory study of nursing student education on spiritual care. J Clin Nurs. 2012;21(13-14):2006-15. DOI: $10.1111 / \mathrm{j} .1365-2702.2011 .04054 . \mathrm{x}$

9. Ross L, van Leeuwen R, Baldacchino D, Giske T, McSherry W, Narayanasamy A, et al. Student nurses' perceptions of spirituality and competence in delivering spiritual care: a European pilot study. Nurse Education Today. 2014;34(5):697-702. Tilgjengelig fra:

https://www.sciencedirect.com/science/article/pii/So260691713003596? casa_token=QOmKQy9SEZQAAAAA:VMroUzmjx8P4GND8YV1FKNRRqa42LUm19 USnr5I4RVfJUnF7r2Pwoc9chfE544-lkK9wPvMTQ_w (nedlastet 15.09.2O21).

10. Hofstad E. Ny prosedyre for å møte pasientens åndelige og eksistensielle behov. Oslo: Sykepleien; 2020. Tilgjengelig fra: https://sykepleien.no/2020/04/nyprosedyre-mote-pasientens-andelige-og-eksistensielle-behov (nedlastet 15.09.2021). 
11. Kleiven T, Crusveller B, Nygaard MR, Miksik S, McSherry W. What do we mean by «spirituality» and «spiritual care?» I: McSherry W. Boughey A, Attard J, red. Enhancing nurses' and midwives' competence in providing spiritual care. Cham: Springer; 2021. s. 21-37.

12. Helsedirektoratet. Palliasjon i kreftomsorgen - handlingsprogram. Oslo: Helsedirektoratet; 2019. Tilgjengelig fra: https://www.helsedirektoratet.no/retningslinjer/palliasjon-i-kreftomsorgenhandlingsprogram (nedlastet 19.08.2021).

13. EPICC Network. Enhancing nurses' and midwives' competence in providing spiritual care through innovative education and compassionate care. EPICC Network. Tilgjengelig fra: http://blogs.staffs.ac.uk/epicc/resources-and-tools/epiccspiritual-care-education-standard/ (nedlastet 19.08.2021).

14. McSherry W, Boughey A, Attard J. Enhancing nurses' and midwives' competence in providing spiritual care. Cham: Springer; 2021.

15. Ross L, Holt J, Kuven BM, Ørskov B. Educational context, evidence and exploration of professional fields og nursing and midwifery. I: McSherry W, Boughey A, Attard J, red. Enhancing nurses' and midwives' competence in providing spiritual care. Cham: Springer; 2021. s. 39-56.

16. Martins AR, Pinto S, Caldeira S, Pimentel F. Translation and adaptation of the spirituality and spiritual care rating scale in Portuguese palliative care nurses. $\mathrm{J}$ Nurs. 2015;4:89-97.

17. Oslo universitetssykehus (OUS). Andelige og eksistensielle behov hos pasienter og pårørende. Retningslinje. Oslo: OUS; u.å. Tilgjengelig fra: https://ehandboken.ous-hf.no/document/134012\#23 (nedlastet 12.01.2022).

18. Kuven BM, Giske T. Talking about spiritual matters: first year nursing students' experiences of an assignment on spiritual conversations. Nurse Education Today. 2019;75:53-7. Tilgjengelig fra: 10.1016/j.nedt.2019.01.012 (nedlastet 08.12.2021).

19. Ødbehr LS, Kvigne K, Hauge S, Danbolt LJ. A qualitative study of nurses’ attitude towards and accommodation of patients' expressions of religiosity and faith in dementia care. J Adv Nurs. 2015;71(2):359-69. 
20. Anandarajah G, Hight E. Spirituality and medical practice: using the HOPE Questions as a practical tool for spiritual assessment. American Family Physician. 2001;63(1):81-9. Tilgjengelig fra: https://www.aafp.org/afp/2001/0101/p81.html (nedlastet 17.06.2021).

21. Oslo universitetssykehus (OUS). Åndelige og eksistensielle behov hos pasienter og pårørende. eHåndbok. Oslo: OUS, u.å. Tilgjengelig fra: https://ehandboken.ous-hf.no/document/134012\#23 (nedlastet 14.09.2021).

22. Giske T, Cone PH. Discerning the healing path - how nurses assist patient spirituality in diverse healing settings. J Clin Nurs. 2015;24(19-29):2926-35. DOI: $\underline{10.1111 / \text { jocn.12907 }}$

23. Weathers E, McCarthy G, Coffey A. Concept analysis of spirituality: an evolutionary approach. Nurs Forum. 2016;51(2):79-96. DOI: $\underline{10.1111 / n u f .12128}$

24. Schiavon CC, Marchetti E, Gurgel LG, Busnello FM, Reppold CT. Optimism and hope in chronic disease: a systematic review. Front Psychol. 2016;7:2022. DOI: $\underline{10.3389 / \text { fpsyg.2016.02022 }}$

25. Broadhurst K, Harrington A. A mixed method thematic review: the importance of hope to the dying patient. J Adv Nurs. 2016;72(1):18-32. DOI: $\underline{10.1111 / \text { jan. } 12765}$

Informasjon om SEP-gruppens arbeid og prosjektet prosjektet finner du på:

- VID nettside: https://www.vid.no/forskning/vids-fremragendeforskningsmiljoer/sep/

- Cristin: https://app.cristin.no/projects/show.jsf?id=2051161

- ResearchGate: https://www.researchgate.net/project/Spiritual-Care-Educationand-Practice-Development-SEP 